\title{
An Analytical study on Male Mammography
}

\author{
Jamil Sheik ${ }^{1}$, Ramgopal $^{2}$ \\ ${ }^{1}$ Assistant Professor, Department of Radio diagnosis, Icare institute of medical sciences Haldia, west Bengal, ${ }^{2}$ Professor, Department of Radio diagnosis, Chalimeda \\ Anandarao of medical college Karimnagar, Telangana.
}

\section{Abstract}

Background: Mammography of male breast accounts for less than $1.5 \%$ of mammographic examinations done in breast imaging centers. In females the awareness of breast cancer is very high when compare to males. Females will undergo periodical screening very frequently through, mammography or clinical examination. The most common presenting symptoms and signs that led to a request for mammogram in these men include an enlargement of breast, a palpable lump, and breast tenderness (1). Aim and study: To know the breast lesions in males through mammography. Subjects and Methods: we have examined breast of 50 Males with the help of mammography. Results: Out of 50 patients. Gynaecomastia is seen in 18 patients. Breast cancer is seen in 4 patients. Conclusion: Routine mammography is very much useful in females for screening of breast cancer. In males also it is useful in ruling out different breast lesions like Gynaecomastia, breast cancer.

Keywords: Gynaecomastia, Male mammography, Breast cancer, Mastitis.

Corresponding Author: Dr. Ramgopal, Professor, Department of Radio diagnosis, Chalimeda Anandarao of medical college Karimnagar, Telangana.

Received: Feb 2018

Accepted: March 2018

\section{Introduction}

Mammography in man usually done to evaluate Gynaecomastia and therefore reports of mammography findings in breast cancer in men are few. The frequency of breast cancers in men is less than $0.1 \%$ of the frequency of breast cancers in woman and breast cancer represents fewer than $0.17 \%$ of all cancers in men. ${ }^{[2]}$ In the United States wide spread screening over last several decades has not been accompanied by a reduction in incidence of metastatic breast cancer despite a large increase in early stage disease, suggesting a substantial amount of over diagnosis at the population level. ${ }^{[3]}$ MRI Screening may be more suited than mammography in women at high risk due to genetic predisposition or in women with very dense breast tissue but specificity may be lower. ${ }^{[4]}$

Breast cancer is a malignant proliferation of epithelial cells lining the ducts or lobules of breast. In the year 2014 about 180,000 cases of invasive breast cancer and 40,000 death has occur in the united states. And 2000 men were diagnosed with breast cancer. ${ }^{[5]}$

\section{Subjects and Methods}

We have examined 50 breasts clinically and mammography was also done. The age group is between 20 years and 70years. Medical charts were reviewed to determine the patients age, risk factor for breast cancer and signs and symptoms. Mammography reports were reviewed to determine the mammography pattern of breast cancer, location of tumor and presence or absence of
Gynaecomastia. $^{[6]}$

\section{Results}

Mammography was done to 50 males patients. Most common age group is 30 years and 50 years. The most common presenting symptoms are unilateral breast enlargement.

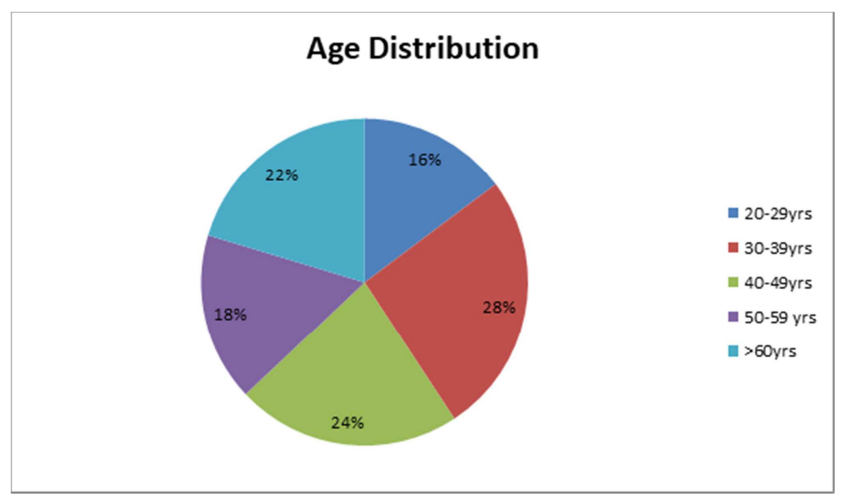

Figure 1: Age distribution

\begin{tabular}{|l|l|l|l|}
\hline $\begin{array}{l}\text { Serial } \\
\text { no. }\end{array}$ & Breast lesion & $\begin{array}{l}\text { No. of } \\
\text { patients }\end{array}$ & Percentage \\
\hline 1 & Gynaecomastia & 17 & $35.5 \%$ \\
\hline 2 & Nonspecific lesions & 19 & $38 \%$ \\
\hline 3 & Breast cancer & 2 & $4 \%$ \\
\hline 4 & Adenoma & 3 & $6 \%$ \\
\hline 5 & Mastitis & 5 & $10 \%$ \\
\hline 6 & Others & 4 & $8 \%$ \\
\hline
\end{tabular}




\section{Jamilsheik o Ramgapal; Analytical study an Male Mammagraphy}

The most common age group involved is 30-50years the common abnormalities are Gynaecomastia 17 is in 17 . (35.5\%) non-specific abnormities are 19 in no. (38\%). Breast cancer is seen in 2 patients (4\%) Adenoma of breast is seen in 3 patients $6 \%$ and mastitis in 5 patients $(8 \%)$ and misselaneous lesion in 4 patients (8\%).

The most common symptons are unilatarl enlargement of breast, pain in the breast and discharge.

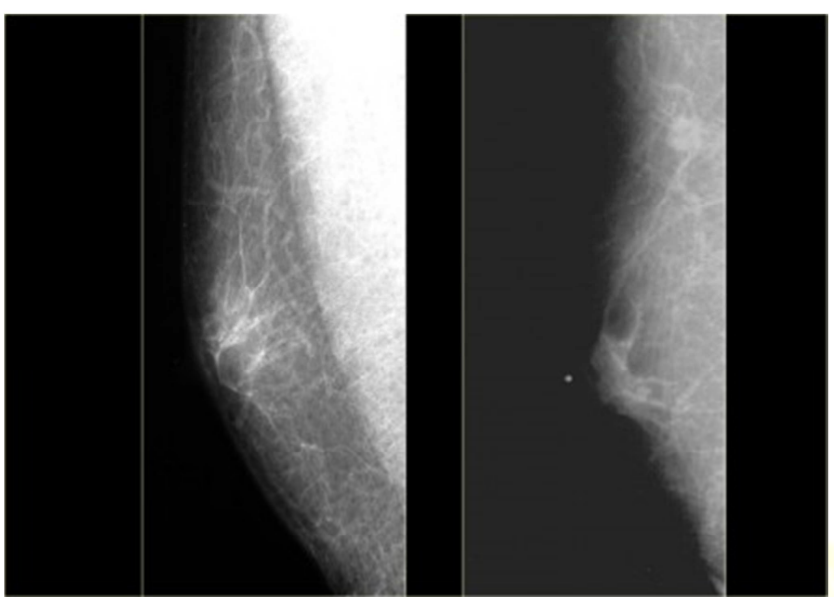

Figure 2(a): Normal male mammography.

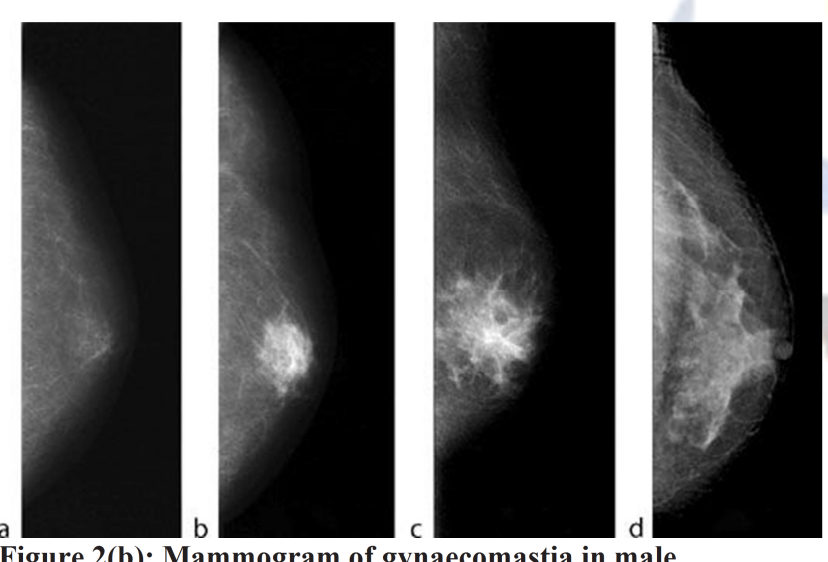

Figure 2(b): Mammogram of gynaecomastia in male

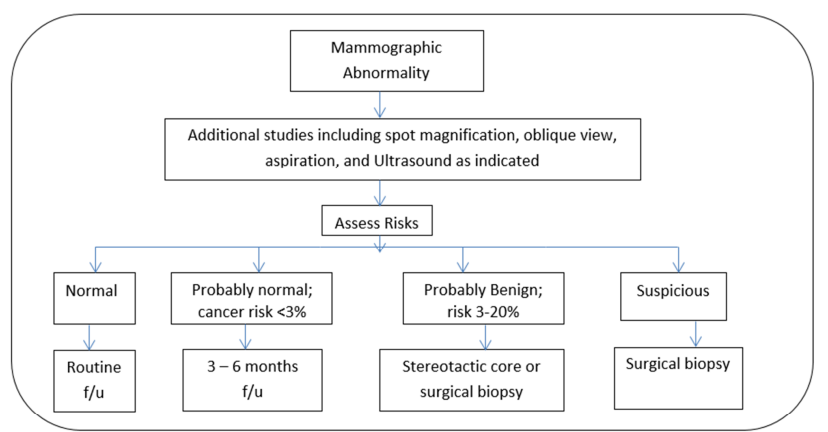

Figure 3: Risk Profile.

\section{Discussion}

Breast cancer is a maligment proliferetion of epithatial cell lining the ducts or lobules of breast. Human breast cancer is a clonal disease, a single transformed cell the product of a series of somatic or germiline mutations. ${ }^{[7]}$

Breast cancer is a harmone dependent disease. Women without functioning ovaries who never receive oestrogen replacement theraphy do not devolop breast cancer. ${ }^{[8]}$

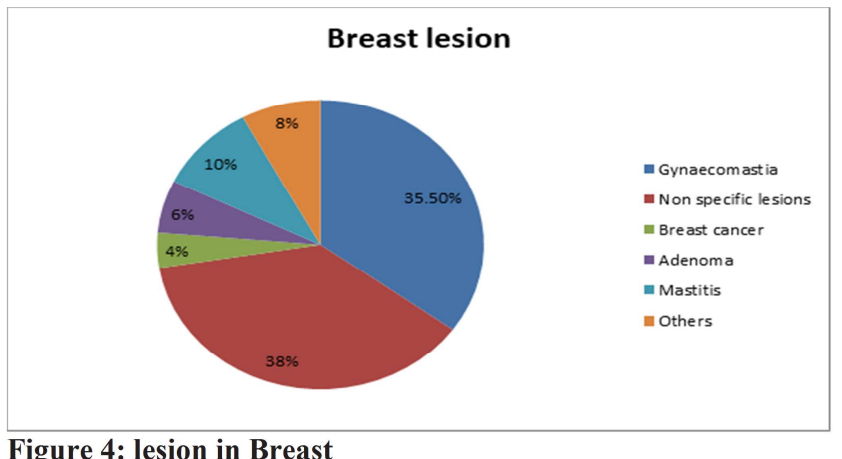

Figure 4: lesion in Breast

Breast cancer is most commonly seen in middle aged or older aged man but it is very rare in males $(0.1 \%)$ when compare to females. The female to male ratio is about 150:1. The 3 factors menarche, age of first full term pregnency, and menopause can account for $70-80 \%$ of variation in breast cancer frequency in different countries. The standard mammographic views, craniocaudal and medio lateral oblique of each breast are routinely performed. In man with uni lateral breast enlargemnet the contra lateral breast may be too small for proper positioning. ${ }^{[8,9]}$

Diagnostic mammography should not be confused with screening mammography which is performed after a palpable abnormality has been detected. Diagnostic mammography in aimed at evaluating the rest of the breast before biopsy is performed. ${ }^{[10]}$ Calcifications that would be accepted as beign in woman can indicate malignant disease in men. ${ }^{[11]}$

If a non-palpable mammographic lesion has a low index of suspicion, mammographic follow up in 3-6 months is reasonable.

Meta-analysis examining outcomes from every randomized trial of mammography conclusively shows a $25-30 \%$ reduction in the chance of dying from breast cancer with annual screening after age 50years. ${ }^{[12]}$

Bather mammographic technology including digitalized mammography, routine use of magnified views, and greater skill in mammographic interpretation, combined with newer diagnostic techniques (MRI and positron emission tomography). May make it possible to identify breast cancer even more reliable and easier. ${ }^{[13]}$

Mammography is the most reliable means of detecting breast cancer before a mass can be palpated. Most slowly growing cancers can be identified by Mammography at least 2 yrs before reaching a size detectable by palpation. ${ }^{[14]}$ The sensitivity of mammography varies from approximately $60 \%$ to $90 \%$. This sensitivity depends on several factors, including, age, breast density, tumor size location \& mammographic appcarancc.

\section{Conclusion}




\section{Jamilsheik d Ramgapal; Analytical study an Male Mammagraphy}

In males breast cancer is very rare. Mammography is very much useful as screening method in decreasing the mortality and morbidity. It is useful in detecting other breast lesions like adenoma, Gynaecomastia and mastitis and some calcified lesions.

\section{References}

1. Boring CC. squires TS. Tony .T cancer statistics -1991. CA cancer J cin.1991;41;19-36.

2. Wain weight JM. Carcinoma of male Breast. Clinical and pathological study. Arch Surg 1927; 14 836-859.

3. Harrison's principles of internal medicine 19th edi.

4. Current medical diagnosis and treatment -2018 edi.
5. Harrison's principles of internal medicine -19th edi.

6. Panethiese Fj. cancer in male breast cancer 1974.34:1324-1327.

7. Short practise of surgery by Baily and Love 27 th edi .

8. Lawin ML. Gynaecomastia: the hypertrophy of male breast J.Clin Endocrinol 1941; 1.511-514.

9. Detraun. P. Benmussa, M. Tristant . H. garall. Breast disease in the galactographic evalution radiology $1985 ; 154$ 605-606

10. Kapdicc parekh NJ the male breast radio. Clin North Am 1983;21:137148.

11. Ouimet- Olive O. webart J.Radiographic characteristics of male breast cancer radiology 1978:129:37-40.

12. Who annual report : statistics on cancer (2017)

13. Harrision's Priniciple's of internal medicine 19th edi.

14. Warner E. clinical practice breast cancer screening . New Engl. J. med. 2011 Sep $.15 ; 365,1025-32$

Copyright: (C) the author(s), publisher. Asian Journal of Medical Radiological Research is an Official Publication of "Society for Health Care \& Research Development". It is an open-access article distributed under the terms of the Creative Commons Attribution Non-Commercial License, which permits unrestricted non-commercial use, distribution, and reproduction in any medium, provided the original work is properly cited.

How to cite this article: Sheik J, Ramgopal. Role of Ultra Sonography in Abdominal Injuries. Asian J. Med. Radiol. Res. 2018;6(1):35-37. DOI: dx.doi.org/10.21276/ajmrr.2018.6.1.9 